\title{
Photochemical Study of Cobalt (II) in Dimethyl Sulfoxide, Simethylformamide and Chloroform Solvents
}

\author{
Farah Ibrahim*, Dheaa Zageer*, Duha Fadhil ${ }^{*}$, Zainab Hussain ${ }^{* *}$, Hadeel Adil* and Emad Yousif* \\ "Department of Chemistry, College of Science, Al-Nahrain University, Baghdad-Iraq. \\ Department of Chemistry, College of Science, Misan University, Misan-Iraq.
}

\begin{abstract}
The photochemistry of chelate complex 2-(6-methoxynaphthalen-2-yl) propanoic acid cobalt (II) $\mathrm{Co}(\mathrm{L})_{2}$ was studied in three polar aprotic solvents: Dimethyl sulfoxide (DMSO), Dimethylformamide (DMF) and chloroform $\left(\mathrm{CHCl}_{3}\right)$. Monochromatic light of wavelength $311 \mathrm{~nm}$ was used for the irradiation process at $25^{\circ} \mathrm{C}$. Uv-visible spectral changes indicated an intra oxidation-reduction reaction occuring during the photolysis of $\mathrm{Co}(\mathrm{L})_{2}$ complex, with homolytic scission of Co-L bond. The quantum yield $\left(\phi_{\mathrm{d}}\right)$, rate of photodecomposition and reactivity ratio $\left(\mathrm{k}_{2} / \mathrm{k}_{-1}\right)$ was determined in each solvent. These values always increase as the polarity of the solvent increases and follow the order: DMSO $>\mathrm{DMF}>\mathrm{CHCl}_{3}$

The mechanism of photodecomposition of this complex under the applied conditions was proposed.
\end{abstract}

Keywords: Photodecomposition, Co(II), DMSO, DMF, Chloroform.

\section{Introduction}

Coordination chemists have been studied the electronic excited states of metal complexes to develop molecular systems for a wide range of applications, solar energy conversion [1], photo catalysis [2] and sensoring [3] to luminescent probes [4] and therapy [5]. The photo deposition method can be used as a general route to deposit the Cobased catalysts on any semiconductor electrode with a valence band edge located at a more positive potential than the oxidation potential of $\mathrm{Co}^{2+}$ ions in solar oxygen evolution[6]. A cobalt complex of a $\mathrm{N}_{2} \mathrm{~S}_{2-}$ tetradentate ligand and CdTe quantum dots displayed a high activity (initial TOF $850 \mathrm{~h}^{-1}$ ) and improved stability (TON $1.44 \times 104$ based on catalyst over $30 \mathrm{~h}$ ) for the photochemical $\mathrm{H} 2$ generation from water, with a quantum efficiency of $5.32 \%$ at $400 \mathrm{~nm}$ [7]. Phthalocyanine complexes with $\mathrm{Zn}^{2+}, \mathrm{Al}^{3+}$, $\mathrm{Ga}^{3+}$ and $\mathrm{Si}^{4+}$ ions show high quantum yield of triplet state and therefore allow to achieve high quantum yield in generation of singlet oxygen and other reactive and cytotoxic oxygen forms. Due to the presence of carboxyl groups, $\mathrm{ZnPcOC}$ exhibits solubility in aqueous solutions i. e. biological systems as well as in organic solvents (DMF, DMSO) [8]. The Co$\mathrm{O}$ transient bond length changes and the optical spectra and kinetics have been measured and compared with those of ferrioxalate. The values presented here strongly suggest that both of these metal oxalato complexes operate under similar photo redox reaction mechanisms where the primary reaction involves the dissociation of a metaloxygen bond. These results also indicate that excitation in the charge-transfer band is not a sufficient condition for the intramolecular electron transfer to be the dominant photochemistry reaction mechanism [9]. The photochemistry of bis(8-quinolinolato) $\mathrm{Cu}(\mathrm{II})$, $\mathrm{Cu}(\mathrm{ox})_{2}$, and bis(8-quinolinethiolato)- $\mathrm{Cu}(\mathrm{II})$, $\mathrm{Cu}(\text { tox })_{2}$, has been studied. Both complexes show solvent-dependent photochemistry when irradiated in $\mathrm{CHCl}_{3}$ and in toluene. The photoproducts of $\mathrm{Cu}$ (tox) $)_{2}$ in $\mathrm{CHCl}_{3}$ are partially reconverted into the initial complex by thermal reaction, while photoreactions of $\mathrm{Cu}(\mathrm{ox})_{2}$ lead to secondary photolytic processes[10].

\section{Experimental \\ Materials}

The 2-(6-methoxynaphthalen-2-yl) propanoic acid Cobalt (II) $\mathrm{Co}(\mathrm{L})_{2}$ complex was prepared by the method described by Ibrahim et al.[11]. 


\section{Techniques}

All photolytic experiments were carried out in thermostated quartz cell of $10 \mathrm{~mm}$ pathlength The photolytic solution were purged by argon gas (purity 99.9\%) for 20 minutes before irradiated at $25^{\circ} \mathrm{C}$. A light source, namely high pressure lamp (1000 W. lwasa Ki Electric Co. Ltd., Japan) was used in conjugation with suitable quartz lens and filter (supplied by Kari-Korb C-mb H, Germany) to give essentially a monochromatic beam of wavelength $311 \mathrm{~nm}$ Calibration of filter with the aid of spectrophotometer showed that the transmitted light was predominantly of wavelength $311 \mathrm{~nm}$. The incident light intensity was determined with ferrioxalate actinometer [12]. UV-Visible spectra and its changes during irradiation experiments were measured using Shimadzu UV-Vis 160A Ultra-violet spectrophotometer.

\section{Results and Discussion}

\section{UV-Visible spectrophotometer}

During irradiation time of the $\mathrm{Co}(\mathrm{II})$ complex in DMSO, DMF and Chloroform, at $25^{\circ} \mathrm{C}$, the colour changes gradually from green to light green in all solvents. The changes in complex spectrum with irradiation time, shows a decrease in the absorbance intensity in the visible region between wavelengths (400-800) $\mathrm{nm}$, at high concentration of the complex solution consideration. The absorbance intensity between (200-400) $\mathrm{nm}$ was decreased with irradiation time at lower concentration of the complexes.

\section{Kinetic use of the UV-Visible}

The decay of the $\operatorname{Co}(\mathrm{L})_{2}$ complex during irradiation at $311 \mathrm{~nm} 25^{\circ} \mathrm{C}$ in different solvents, has been followed by monitoring the concentration of this complex spectrophotometrically, from the logarithm plots of the $A_{t}-A_{\infty}$ versus time, the values of the first order specific rate constant $\left(k_{d}\right)$ for the complex in different solvents have been determined where $A_{t}$ is the absorbance of the complex solution at selected wavelength. $A_{\infty}$ is the absorbance of the same solution after prolonged irradiation. From the variations of $\ln \left(A_{t}-A_{\infty}\right)$ with irradiation time $(t)$ of complex the specific rate constants $\left(\mathrm{k}_{\mathrm{d}}\right)$ for $\mathrm{Co}(\mathrm{II})$ complex were obtained. Table (1) shows the value of light intensity ( $\mathrm{I}_{\mathrm{Abs}}$ ), the specific rate constant $\left(\mathrm{k}_{\mathrm{d}}\right)$, the quantum yield $\left(\mathrm{Q}_{\mathrm{d}}\right)$ and reactivity ratio $\left(\mathrm{K}_{2} / \mathrm{K}_{-1}\right)$ of the $\mathrm{Co}(\mathrm{II})$ complex in all solvents used under same conditions. The results indicate that the $\mathrm{k}_{\mathrm{d}}$ and $\mathrm{Q}_{\mathrm{d}}$ values are dependent on the type of solvent used. They always increase as the polarity of the solvent increases and follow the order:

\section{$\mathrm{DMSO}>\mathrm{DMF}>\mathrm{CHCl}_{3}$}

The variation of the values of quantum yield with dielectric constant values of solvents are shown in Fig.(1). These results are shown in this Figure. Generally, indicate that $\mathrm{Q}_{\mathrm{d}}$ increases as the dielectric constant increases; and this might point out to the ionic nature of the excited transition state of the $\mathrm{Co}(\mathrm{II})$ complex in these solvents.

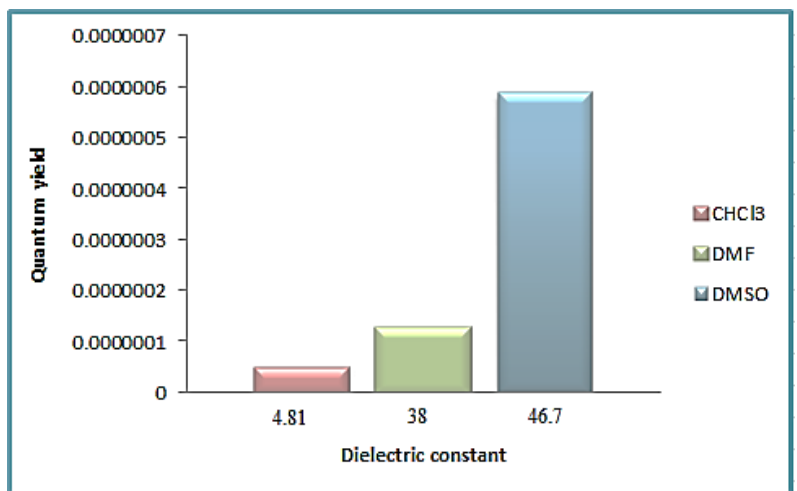

Fig.(1): Quantum yields $\left(Q_{d}\right)$ with the dielectric constant of the solvent for the photodecomposition of $\mathrm{Co}(L)_{2}$ complex in different polar aprotic solvents.

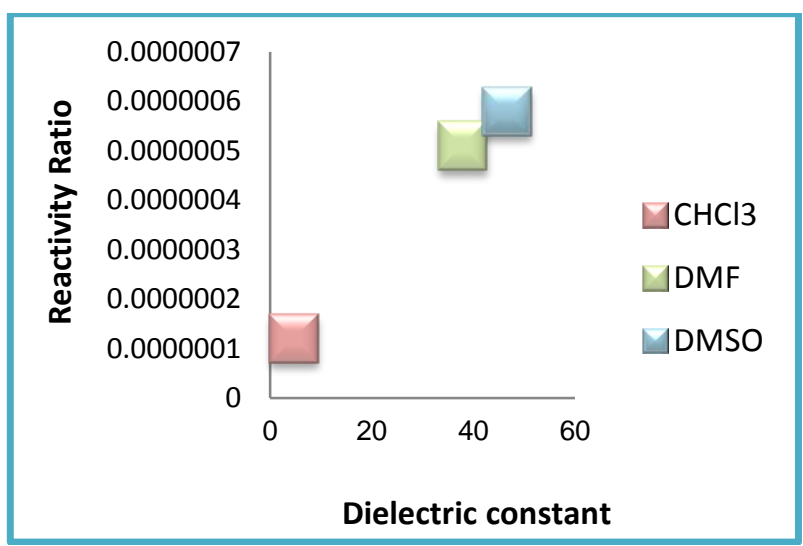

Fig.(2): Reactivity ratio with the dielectric constant of each solvent for the photodecomposition of $\mathrm{Co}(L)_{2}$ complex. 


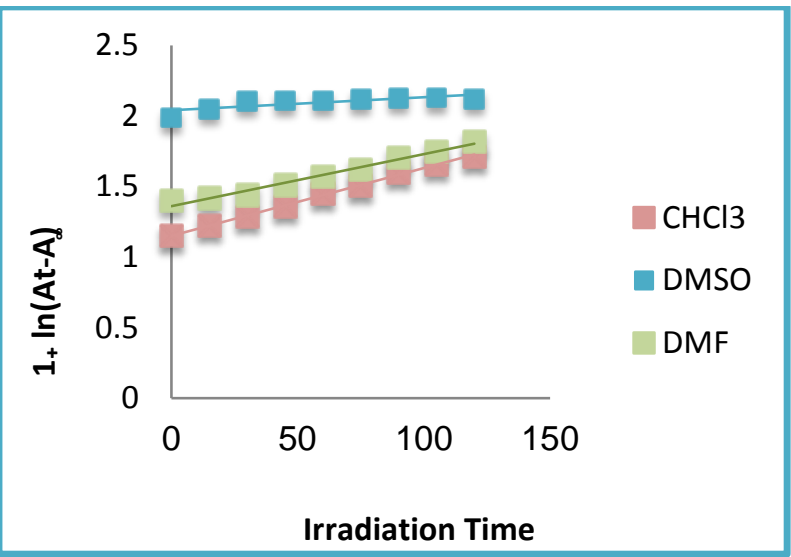

Fig.(3): Variation of $\ln \left(A_{t}-A_{\infty}\right)$ of $C o(L)_{2}$ complex with irradiation time in different solvents.

Mechanism of the 2-(6-methoxynaphthalen2-yl) propanoic acid cobalt (II) photodecomposition.

The UV-Visible spectral changes are related to the photolytic products and other species that are produced upon. The following mechanism (Eq.(1-8)) may be suggested for the photodecomposition process.

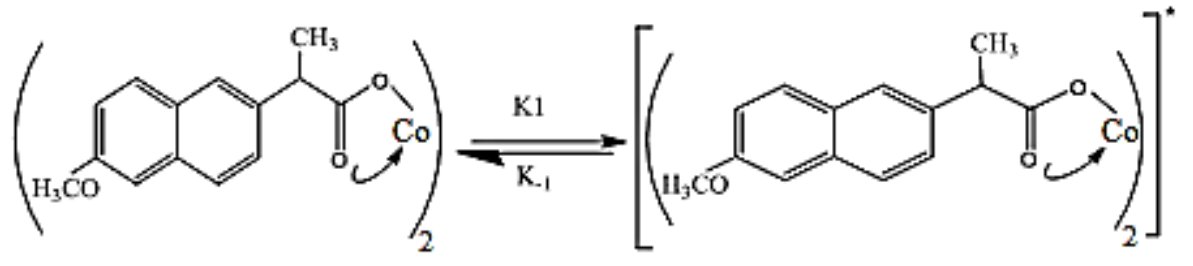

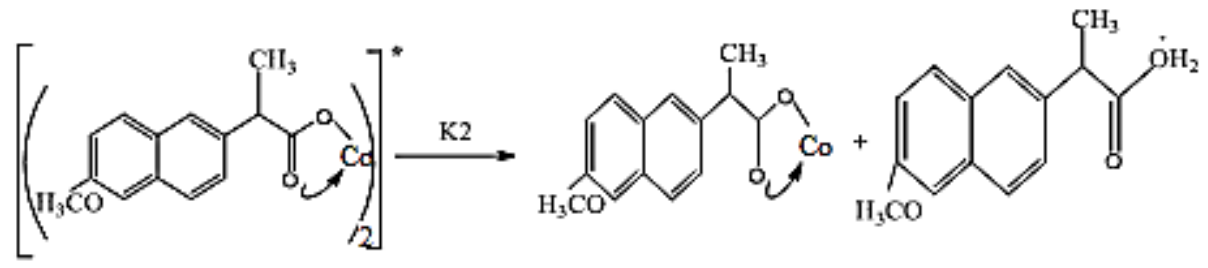<smiles>[Y3]C(C)Cc1ccc2cc(C(C)C(=O)OOC(=O)C(C)c3ccc4cc(OC)ccc4c3)ccc2c1OC</smiles><smiles>COc1ccc2cc(C(C)C(=O)[O-])ccc2c1</smiles>

$$
\mathrm{D}^{\cdot}+\mathrm{D} \stackrel{\mathrm{K}_{5}}{\longrightarrow} \mathrm{D}-\mathrm{D}
$$


The low values of quantum yields of Photodecomposition process indicate that the deactivation of the photo excited chelate $\left(\mathrm{K}_{-1}\right)$ is an important process on this mechanism.

The rate of decomposition $=\mathrm{l}_{\mathrm{Abs}}-\frac{\mathrm{I}_{\mathrm{Abs}} \mathrm{K}_{\cdot \mathrm{l}}}{\mathrm{K}_{-1}+\mathrm{K}_{2}}-\frac{\mathrm{d}[\mathrm{CoL} 2]}{\mathrm{dt}}$

$\mathrm{Q}_{\mathrm{d}}=\frac{\text { rate of photodecomposition }}{\mathrm{I}_{\mathrm{Abs}}}$

than

$$
\frac{\mathrm{K}_{2}}{\mathrm{~K}_{-1}}=\frac{\mathrm{Q}_{\mathrm{d}}}{1-\mathrm{Q}_{\mathrm{d}}}
$$

\section{Conclusion}

In this work, the photochemical of chelate complex 2-(6-methoxynaphthalen-2yl)propanoic acid cobalt (II) $\mathrm{Co}(\mathrm{L})_{2}$ using three solvents: dimethyl sulfoxide, dimethylformamide, chloroform was studied. The quantum yield $\left(\mathrm{Q}_{\mathrm{d}}\right)$, rate of photodecomption and reactivity ratio $\left(\mathrm{k}_{2} / \mathrm{k}_{-1}\right)$ was determined in each solvent. These values increase as the polarity of the solvent increases and follow the order: DMSO $>\mathrm{DMF}>\mathrm{CHCl}_{3}$.

\section{Acknowledgment}

The authors acknowledge the Department of Chemistry, College of Science, Al-Nahrain University.

\section{References}

[1] Gust D., Moore A., Moore L., Solar fuels via artificial photosynthesis. Acc. Chem. Res., 42 1890-1898, 2009.

[2] Teets S., Nocera G., Photocatalytic hydrogen production. Chem. Commun., 47, 9268-9274, 2011.

[3] Ruggi A., Van Leeuwen B., Velders H., Interaction of dioxygen with the electronic excited state of $\operatorname{Ir}(\mathrm{III})$ and $\mathrm{Ru}(\mathrm{II})$ complexes: principles and biomedical applications, Coord. Chem. Rev., 255, 2542-2554, 2011.

[4] Lakowicz R., Principles of fluorescence spectroscopy, 3rd edn. New York, NY: Springer, 2006.
[5] Farrer J., Salassa L., Sadler J., Photoactivated chemotherapy (PACT): the potential of excited-state d-block metals in medicine. Dalton Trans, 10, 690-701, 2009.

[6] Ellen P., Kyoung-Shin C., Photochemical deposition of cobalt-based oxygen evolving catalyst on a semiconductor photoanode for solar oxygen production. PNAS, 106 (49): 20633-20636, 2009.

[7] Kai H., Mei W., Shuai Z., Suli W., Yong Y., Licheng S., Photochemical hydrogen production from water catalyzed by CdTe quantum dots/molecular cobalt catalyst hybrid systems. Chem. Commun., 51, 7008-7011, 2015.

[8] Joanna N., Artur S., Marta K., Octa carboxyphthalo cyanines compounds of interesting spectral, photochemical and catalytic properties. CHEMIK, 68 (4): 369 376, 2014.

[9] Jie C., Hua Z., Ivan T., Xunliang D., Peter R., Photochemistry and electron-transfer mechanism of transition metal oxalato complexes excited in the charge transfer band. PANS, 105 (40): 2008.

[10] Bojana J., Julia P., Charge Transfer Photochemistry of $\mathrm{Bis}(8-$ quinolinolato) copper(II) and Bis(8-quinolinethiolato) copper(II) in Aprotic Solvents, Zeitschrift für Naturforschung B., 50 (4): 524-528, 2014.

[11] Ibrahim F., Ameer A., Yousif E., Synthesis, characterization and spectroscopic of some transition metal complexes with 2-(6-methoxynaphthalene2-yl)propanoic acid. International journal of research in pharmacy and chemistry, 4, 299-302, 2014.

[12] Brann D., Rabie S., Khaireldin N., Abdel Gaffar M., Preparation and Evaluation of Some Benzophenone Terpolymers as Photostabilizers for Rigid PVC, Journal of Vinyl and Additives Technology., 17, 47155, 2011. 


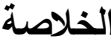

تم دراسة الكيمياء الضوئية لمعقد الكوبلت الثنائي مع

الليكاند ثنائي السن:

-methoxynaphthalen-2-yl)propanoic acid

6)-2 في ثلاث مذيبات قطبية لا بروتونية هي: ثنائي مثنيل

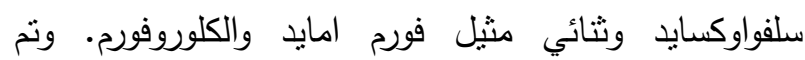

استخدام ضوء أحادي وبطول موجي قدره 311 نانوميتز

وبدرجة حرارة 25هم. لقد دلت التغيرات الطيفية الحاصلة

على حصول تفاعل أكسدة-اختزال داخلي خلال عملية 2 مع

انفصام متجانس للآصرة Co-L. لقد تم حساب الناتج الكمي

وسرعة التفكلى الضوئي ونسبة الفعالية Qd

مذيب من المذيبات أعلاه ووجد ان هذه القيم تزداد بزيادة

$$
\text { قطبية المذيب ووفق الترنيب الآتي: }
$$

DMSO > DMF $>\mathrm{CH}_{3} \mathrm{Cl}$

ووفقا للنتائج العملية المستحصلة، تم أقتراح ميكانيكية

التفكك الضوئي لمعقد الكوبلت الثنائي. 